\title{
The role of GST omega in metabolism and detoxification of arsenic in clam Ruditapes philippinarum
}

\author{
Lizhu Chen ${ }^{\mathrm{a}, \mathrm{c}}$, Huifeng $\mathrm{Wu}^{\mathrm{a}, \mathrm{b}, *}$, Jianmin Zhao ${ }^{\mathrm{a}}$, Wei Zhang ${ }^{\mathrm{d}}$, Li Zhang ${ }^{\mathrm{d}}$, Shan Sun ${ }^{\mathrm{c}}$, \\ Dinglong Yang ${ }^{\mathrm{a}}$, Bo Cheng ${ }^{\mathrm{e}}$, Qing Wang ${ }^{\mathrm{a}, *}$ \\ ${ }^{\text {a }}$ Key Laboratory of Coastal Zone Environmental Processes and Ecological Remediation, Yantai Institute of Coastal Zone Research, Chinese Academy of Sciences, Yantai \\ 264003, PR China \\ ${ }^{\mathrm{b}}$ Laboratory for Marine Fisheries Science and Food Production Processes, Qingdao National Laboratory for Marine Science and Technology, Qingdao 266237, PR China \\ ' Shandong Marine Resource and Environment Research Institute, Yantai 264006, PR China \\ ${ }^{\mathrm{d}}$ Key Laboratory of Tropical Marine Bio-resources and Ecology, South China Sea Institute of Oceanology, Chinese Academy of Sciences, Guangzhou 510301, PR China \\ e Aquatic Products Quality and Standards Research Center, Chinese Academy of Fishery Sciences, Beijing 100141, PR China
}

\section{A R T I C L E I N F O}

\section{Keywords:}

Arsenic

Bioaccumulation

Metabolism

Subcellular distribution

Glutathione S-transferase omega

\begin{abstract}
A B S T R A C T
The major hazard of arsenic in living organisms is increasingly being recognized. Marine mollusks are apt to accumulate high levels of arsenic, but knowledge related to arsenic detoxification in marine mollusks is still less than sufficient. In this study, arsenic bioaccumulation as well as the role of glutathione S-transferase omega (GST $\Omega$ ) in the process of detoxification were investigated in the Ruditapes philippinarum clam after waterborne exposure to As(III) or As(V) for 30 days. The results showed that the gills accumulated significantly higher arsenic levels than the digestive glands. Arsenobetaine (AsB) and dimethylarsenate (DMA) accounted for most of the arsenic found, and monomethylarsonate (MMA) can be quickly metabolized. A subcellular distribution analysis showed that most arsenic was in biologically detoxified metal fractions (including metal-rich granules and metallothionein-like proteins), indicating their important roles in protecting cells from arsenic toxicity. The relative mRNA expressions of two genes encoding GST $\Omega$ were up-regulated after arsenic exposure, and the transcriptional responses were more sensitive to As(III) than As(V). The recombinant GST $\Omega$ s exhibited high activities at optimal conditions, especially at $37^{\circ} \mathrm{C}$ and $\mathrm{pH} 4-5$, with an As(V) concentration of $60 \mathrm{mM}$. Furthermore, the genes encoding GST $\Omega$ significantly enhance the arsenite tolerance but not the arsenate tolerance of $E$. coli AW3110 (DE3) ( $\triangle a r s R B C$ ). It can be deduced from these results that GST $\Omega$ s play an important role in arsenic detoxification in $R$. philippinarum.
\end{abstract}

\section{Introduction}

Arsenic, which naturally exists in the earth's crust, is a highly toxic metalloid. It is known that arsenic can lead to human skin cancer and other diseases (Akter et al., 2005; Jomova et al., 2011). With the increase in ore mining activity, the use of arsenical pesticides and the emission of industrial waste into the sea, arsenic pollution is becoming increasingly serious in coastal areas of China (Luo et al., 2010; Xu et al., 2013; Gao et al., 2014). Arsenic content in offshore marine organisms in China has been recently reported at high concentrations. For example, the total arsenic in the fish Trypauchen vagina collected from Zhanjiang (Guangdong, China) was as high as $134 \mu \mathrm{g} / \mathrm{g}$ dry weight (dw) (Zhang and Wang, 2012). It has been widely reported that marine animals such as mollusks, crustaceans and fish typically have high concentrations of arsenic in their tissues, ranging from less than $1 \mu \mathrm{g} / \mathrm{g}$ dw to more than $100 \mu \mathrm{g} / \mathrm{g} \mathrm{dw}$ (Katano et al., 2003; Neff, 1997; Zhang et al., 2013). In marine animal samples, the less toxic organic arsenic constituted most arsenic compounds, and inorganic arsenic generally occurred at levels below $2 \%$ for the total arsenic (Li et al., 2003a; Waring and Maher, 2005; Zhang et al., 2013). However, the concentrations of inorganic arsenic in two cultured marine fishes collected from Fujian province (China), Pagrus major and Lateolabrax japonicus, are up to 2.8 and $4.5 \mu \mathrm{g} / \mathrm{g} \mathrm{dw}$, respectively; the levels are much higher than China's national standard for inorganic arsenic in seafood $(0.5 \mu \mathrm{g} / \mathrm{g} \mathrm{dw})$ and may pose a significant threat to human health (Onsanit et al., 2010).

Arsenic has a variety of chemical forms in nature, and its toxicity depends greatly on its chemical species. Marine organisms generally contain high concentrations of arsenic, most of which are present as

\footnotetext{
* Corresponding author at: Key Laboratory of Coastal Zone Environmental Processes and Ecological Remediation, Yantai Institute of Coastal Zone Research, Chinese Academy of Sciences, Yantai 264003, PR China.

E-mail addresses: hfwu@yic.ac.cn (H. Wu), qingwang@yic.ac.cn (Q. Wang).
} 
nontoxic organic species such as AsB, arsenocholine and arsenosugars (Li et al., 2003a; Fattorini et al., 2004a). Arsenic mainly exists in hypertoxic inorganic arsenic forms of As(III) and As(V) in soil and water (Fattorini et al., 2004a; Francesconi and Edmonds, 1996). General studies show that the toxicity of As(III) is higher than As(V), and methylated pentavalent arsenic compounds such as MMA and DMA are moderately toxic (Rahman and Hassler, 2014). However, recent studies have shown that MMA(III) and DMA(III) exhibit higher toxicity and carcinogenicity than As(III) and As(V) (Akter et al., 2005; Ventura-Lima et al., 2011a).

To date, systematic studies on the molecular mechanism of arsenic metabolism have been done on mammals, bacteria, microalgae and some invertebrates (Qin et al., 2006, 2009; Thomas et al., 2010; Yin et al., 2011). It is generally accepted that the arsenic metabolism process involves successive reductions followed by oxidative methylation reactions (Aposhian et al., 2004; Vahter, 2002), and glutathione-Stransferase omega (GST $\Omega$ ) has been shown to be a key enzyme involved in the limiting step of the metabolism process (Sampayo-Reyes and Zakharyan, 2006; Zakharyan and Aposhian, 1999; Zakharyan et al., 2001). For example, human GSTS 1-1, identified as a MMA(V) reductase, is able to catalyze the reductions of $\mathrm{As}(\mathrm{V})$ to $\mathrm{As}(\mathrm{III}), \mathrm{MMA}(\mathrm{V})$ to MMA(III), and DMA(V) to DMA(III) (Chowdhury et al., 2006; Zakharyan et al., 2001). Moreover, the level of GST $\Omega$ activity has been used as an estimation of the capability of an organism to metabolize inorganic arsenic (Aposhian et al., 2004; Sampayo-Reyes and Zakharyan, 2006; Ventura-Lima et al., 2009, 2011b). At present, GST $\Omega$ homologues have also been widely characterized in marine invertebrates such as polychaetes and mollusks (Ventura-Lima et al., 2011a). However, data on the role of GST $\Omega$ in the detoxification of arsenic in marine organisms are still limited.

Ruditapes philippinarum clams, which are widely distributed in nearshore and estuarine areas, have been widely used in marine ecotoxicology studies because of their high accumulation of metals and other pollutants (Liu et al., 2011). R. philippinarum is also one of the bioindicators of the "Mussel Watch Plan" in China, which makes it ideal for studying the bioaccumulation and detoxification mechanism of arsenic. By now, at least five major classes of GSTs (sigma, omega, mu, rho, microsomal) have been characterized in this clam (Zhang et al., 2012b). Distinguished from other subtypes of GST proteins, GST $\Omega$ possesses cysteine residues in its active site, exhibits a number of atypical structural and functional features, and may function as an arsenate reductase during the arsenic detoxification process (Sampayo-Reyes and Zakharyan, 2006; Yin et al., 2001). Additionally, a preliminary transcriptomic study shows that GST $\Omega$ s are significantly up-regulated after arsenic exposure, while the transcripts of other GSTs are not significantly modulated (unpublished data). Thus, further work is needed to clarify the possible function of GSTQs in arsenic detoxification in this clam. The aim of this work was to investigate the arsenic bioaccumulation and metabolism of inorganic arsenic in the clam tissues as well as the possible role of GST $\Omega$ in these processes.

\section{Materials and methods}

\subsection{Clam and sample collection}

Healthy clams (shell length: $3.0-4.0 \mathrm{~cm}$ ) obtained from a local culture farm in Yantai (China) were acclimatized in aerated and filtered seawater $\left(13{ }^{\circ} \mathrm{C}, 31 \%\right.$, $\left.\mathrm{pH} 7.9\right)$ for 10 days before the exposure experiment. The clams were fed with Chlorella vulgaris throughout the acclimatization and experiment, and the seawater was completely changed daily after a 2-hour feeding.

The stock solutions of $\mathrm{As}(\mathrm{V})$ and $\mathrm{As}(\mathrm{III})$ were prepared with $\mathrm{Na}_{3} \mathrm{AsO}_{4}$ (Chem Service, USA) and $\mathrm{NaAsO}_{2}$ (Sinopharm Chemical Reagent Co. Ltd, China) at a concentration of $0.1 \mathrm{mg} / \mathrm{mL}$, respectively. The average concentration of arsenic in the water column of Bohai Sea is about $1 \mu \mathrm{g} / \mathrm{L}$, like that of the oceans (Gao et al., 2014; Neff, 1997).
However, in some seriously polluted areas such as the estuarine areas of southern Bohai Sea, the average dissolved concentration of As in the water was $18.6 \mu \mathrm{g} / \mathrm{L}$, with a highest value of $347.7 \mu \mathrm{g} / \mathrm{L}$ (Xu et al., 2013). Thus, exposure concentrations of $10 \mu \mathrm{g} / \mathrm{L}$ and $100 \mu \mathrm{g} / \mathrm{L}$ were used in our study to investigate the toxic effects of arsenic on the bivalves in the above area. The clams were randomly divided into fifteen aquaria, and each group contained 30 individuals. Three tanks without any treatment served as the control group, while the other twelve tanks were exposed to $\mathrm{As}(\mathrm{V})$ or $\mathrm{As}(\mathrm{III})$ at final concentrations of 10 and $100 \mu \mathrm{g} / \mathrm{L}$, respectively, each with three replicates. After a 30-day exposure, the gills and digestive glands of the clams were collected. The samples for the total RNA extraction were immersed in a TRIzol reagent (Invitrogen, USA) and stored at $-80^{\circ} \mathrm{C}$, while the others were directly kept at $-80^{\circ} \mathrm{C}$ until analysis. The seawater in the control group and exposure groups was also sampled to assess the natural background value of the arsenic.

\subsection{Determination of total arsenic content in clam tissues}

The total arsenic content in the clam tissues was measured following previously described and validated procedures (Zhang et al., 2012a). The frozen tissue samples were dried at $50{ }^{\circ} \mathrm{C}$ to a constant weight and $1 \mathrm{~mL}$ of concentrated $\mathrm{HNO}_{3}$ added $(65 \%$, analytical reagent grade, Fisher Scientific). Subsequently, the samples were heated in a water bath at $80^{\circ} \mathrm{C}$ until complete digestion and then were diluted to $10 \mathrm{~mL}$ with double deionized water. All experiments were tested with certified oyster tissue material (NIST SRM 1566b, National Institute of Standard and Technology, USA). The total arsenic content was determined by an inductively coupled plasma mass spectrometer (ICP-MS) (PerkinElmer, Elan DRCII, USA) with In (115) $(1.0 \mu \mathrm{g} / \mathrm{mL}$, Agilent, USA) as an internal standard solution. The arsenic standard solution was prepared from a stock solution (GBW08611, Chinese National Standards). The total arsenic recovery rate of the certified material was $95.8 \%$. The total arsenic content in the tissues was shown to be $\mu \mathrm{g} / \mathrm{g} \mathrm{dw}$ with four parallel samples for each group.

\subsection{Arsenic speciation analysis}

Arsenic speciation in tissues was detected using HPLC-UV-HG-AFS (AF-610D2, Beifenruili Analytical Instrument Corp., Beijing, China) following the protocol of Zhang et al. (2015). Five $\mathrm{mL}$ of $50 \%$ methanol solution were added to the samples, which were then homogenized for $15 \mathrm{~min}$. The homogenates were centrifuged twice $(10,000 \mathrm{rpm}, 10 \mathrm{~min})$ to obtain a supernatant, which was evaporated to remove the organic solvent, after which it was diluted with double deionized water. Finally, the digests were filtered through $0.45 \mu \mathrm{m}$ filters for an arsenic speciation analysis. The test conditions were as follows: Anion exchange column: Hamilton PRP-X100 (10 microns, $250 \mathrm{~mm}$ x $4.1 \mathrm{~mm}$ ); mobile phase: $20 \mathrm{mmol} / \mathrm{L} \mathrm{NH}_{4} \mathrm{HCO}_{3}, 10 \mathrm{mmol} / \mathrm{L} \mathrm{KCl}, \mathrm{pH} \mathrm{10.3}$; current-carrying: $10 \%(\mathrm{v} / \mathrm{v}) \mathrm{HCl}$; reducing agent: $2 \%$ of $\mathrm{KBH}_{4}$ in $0.2 \% \mathrm{KOH}(\mathrm{w} / \mathrm{v})$; antioxidant: $2 \%(\mathrm{~m} / \mathrm{v}) \mathrm{K}_{2} \mathrm{~S}_{2} \mathrm{O}_{8}$ in $0.5 \% \mathrm{KOH}(\mathrm{w} / \mathrm{v})$; shielding gas: $800 \mathrm{~mL} / \mathrm{min}$; carrier gas: $500 \mathrm{~mL} / \mathrm{min}$; Lamp current: $100 \mathrm{~mA}$. There were three repetitions in each group.

Quality assurance was done with analyses of standard reference materials - BCR-627 tuna from the Institute for Reference Materials and Measurements (Geel, Belgium). BCR-627 tuna fish tissue $(0.1 \mathrm{~g})$ was used for AsB and DMA analysis. The certified values of AsB and DMA in this certified reference material were $3.90 \pm 0.22 \mu \mathrm{g} / \mathrm{g}$ and $0.15 \pm 0.02 \mu \mathrm{g} / \mathrm{g}$, respectively. With our method, we obtained an AsB concentration of $4.41 \pm 0.03 \mathrm{~g} / \mathrm{g}(113 \%$ recovery, $n=6)$ and a DMA concentration of $0.14 \pm 0.02 \mathrm{~g} / \mathrm{g}$ (93\% recovery, $n=6)$. Spikes were also used to confirm the recovery of other As species detected during the speciation analysis. In our study, As(III) recoveries were $78-106 \%$, As $(\mathrm{V})$ recoveries were $82-101 \%$, and MMA recoveries were $87-103 \%$. 


\subsection{Subcellular arsenic distribution}

Five subcellular components, including organelles, heat sensitive proteins (HSP), metallothionein-like proteins (MTLPs), metal-rich granules (MRG) and cellular debris, were fractionated by differential centrifugation to determine the subcellular arsenic distribution (Wallace and Luoma, 2003; Zhang et al., 2015). After the samples were weighed, the clam tissues were homogenized in a $20 \mathrm{mM}$ Tris $-\mathrm{HCl}$ buffer ( $\mathrm{pH}$ 7.6) infused with 2-mercaptoethanol $(5 \mathrm{mM})$ and phenylmethanesulfonyl fluoride $(0.1 \mathrm{mM})$ on ice. The five fractions were then obtained as described by Zhang et al. (2015). Afterward, the five fractions were digested, and the total arsenic concentration in each fraction was determined by ICP-MS. The SRM 1566b oyster tissue was analyzed to evaluate the accuracy of the method. The sum of the arsenic content in the five fractions was $75-108 \%$ of the certified value in the reference material, showing low recovery efficiency. This was mainly caused by a loss of arsenic in different fractions during measurements. The result was shown as a percentage of arsenic in each fraction with a percentage error of lower than $5 \%$. Each group contained four parallel samples.

\subsection{Arsenate reductase assay of GSTS}

GSTs were purified from the gills and digestive glands of the clams using a commercial kit (MagneGST ${ }^{\mathrm{TM}}$ Glutathione Particles, Promega, USA). The arsenate reductase activity of GST $\Omega$ was measured using a previous method (Sampayo-Reyes and Zakharyan, 2006; Ventura-Lima et al., 2011b). Briefly, the protein was incubated at $37^{\circ} \mathrm{C}$ in $0.1 \mathrm{M}$ Tris $-\mathrm{HCl}$ (pH 7.4) containing 0.25 mM NADPH, $0.8 \mathrm{U}$ glutathione reductase, $5 \mathrm{mM} \mathrm{GSH}$, and $40 \mathrm{mM} \mathrm{As}(\mathrm{V})$ for $10 \mathrm{~min}$. The reductase activities were monitored spectrophotometrically at $340 \mathrm{~nm}$ (U-3900H, Hitachi, Japan) and were shown as the decrement of NADPH. The extinction coefficient of NADPH is $6.22 \mathrm{mM} / \mathrm{cm}$, and each treatment had three or four repeats.

\subsection{Quantitation of GST $\Omega$ transcripts}

The qRT-PCR reactions were carried out to analyze the expressions of GST 1 and GSTS 2 in the gills and digestive glands of the clams (Yang et al., 2010). The total RNA was extracted and used to synthesize the cDNA with an oligo-dT primer (Table 1). After the reverse transcription, the relative mRNA expressions of GST $\Omega$ s were assayed in an Applied Biosystem 7500 Real-time PCR System. $\beta$-actin was used as an internal control to verify the successful transcription and to calibrate the cDNA template (Zhang et al., 2012b). The gene-specific primers for GST $\Omega$ s and $\beta$-actin were listed in Table 1 . The reaction conditions were as follows: $50^{\circ} \mathrm{C}$ for $2 \mathrm{~min}$, followed by 40 cycles of $95^{\circ} \mathrm{C}$ for $10 \mathrm{~min}$, $95^{\circ} \mathrm{C}$ for $15 \mathrm{~s}$, and $60^{\circ} \mathrm{C}$ for $1 \mathrm{~min}$. The quantitative analysis of expressions of GST $\Omega$ genes was performed using the $2^{-\triangle \triangle \mathrm{CT}}$ method. All data were given as the mean \pm S.E. $(n=4-6)$.

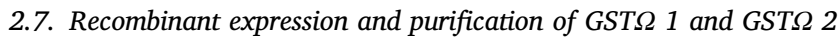

The genes encoding GST $\Omega 1$ and GST 22 were amplified by PCR with two pairs of gene-specific primers, with BamH I and Hind III sites at their $5^{\prime}$ ends, respectively, as described in Table 1 (Wang et al., 2012). The sequences were confirmed by Sanger sequencing (SinoGenoMax, Beijing, China) and were then cloned into pET-28a vectors (Novagen, USA). Afterwards, the recombinant plasmids were overexpressed in Escherichia coli BL21 (DE3) (Novagen, USA). The recombinant proteins were purified using HisTrap affinity columns (GE Healthcare, USA) and dialyzed with $20 \mathrm{mM}$ Tris - $\mathrm{HCl}$ ( $\mathrm{pH}$ 8.0) containing $60 \mathrm{mM} \mathrm{NaCl}$ and $5 \mathrm{mM}$ dithiothreitol (DTT) (Sampayo-Reyes and Zakharyan, 2006). The peptides were analyzed by SDS-PAGE with separation in a $15 \%$ gel followed by Coomassie brilliant blue R250 staining. Moreover, the concentrations of recombinant proteins were measured with the Bradford method. The recombinant proteins were stored at $-80^{\circ} \mathrm{C}$ until use.

\subsection{Polyclonal antibody preparation and western blotting analysis}

The polyclonal antibodies of GST $\Omega$ s were produced by immunizing the mice (Luye Pharma Inc., Yantai, China) with the recombinant proteins (Yang et al., 2010). The serum of one mouse injected with PBS served as the negative control. Afterwards, the specificity of the antibodies was confirmed by a western blotting analysis. After the proteins were separated by SDS-PAGE, the gels were transferred to PVDF membranes. The membranes were then respectively incubated with polyclonal antibodies (1:1000 dilution) followed by a reaction with alkaline phosphatase (AP)-conjugated secondary goat anti-mouse IgG (1:3000 dilution, Beyotime, China). The western blotting was developed by NBT/BCIP (Beyotime, China) and terminated by washing the PVDF membranes with deionized distilled water.

\subsection{Immunohistochemistry}

The fresh tissues of the gills and digestive glands were fixed in $4 \%$ paraformaldehyde solution, dehydrated in ethanol, embedded in paraffin and sectioned at $5 \mu \mathrm{m}$. The endogenous alkaline phosphatase was blocked by incubating the slides in $3 \%$ acetic acid for $10 \mathrm{~min}$. For antigen retrieval, the slides were boiled in a $0.01 \mathrm{M}$ citrate buffer at $120^{\circ} \mathrm{C}$ for $6 \mathrm{~min}$. Endogenous peroxidase activity was blocked with $3 \%$ hydrogen peroxide in methanol for $10 \mathrm{~min}$. The slides were incubated with primary polyclonal antibodies of GST $\Omega 1$ and GST $\Omega 2$ (1:500) and washed with PBST (0.01 M PBS, $0.05 \%$ Tween 20$)$. The slides were then incubated with biotinylated goat anti-mouse IgG (1:200, Solarbio, China) followed by incubation with streptavidin labeled with alkaline phosphatase (1:300, Beyotime, China). The immunostaining was visualized using the AP-Red Kit (ZSGB-BIO Origene, China), and the slides were counterstained with hematoxylin. In negative controls, the primary antibodies were substituted with the serum of a mouse immunized with PBS.

Table 1

Primer sequences used in this study.

\begin{tabular}{|c|c|c|}
\hline Primer & Sequence (5'-3') & Sequence information \\
\hline oligo-dT & GGCCACGCGTCGACTAGTACT $_{17}$ & primer for cDNA synthesis \\
\hline$\beta$-actin-F & CTCCCTTGAGAAGAGCTACGA & qRT-PCR primer for $\beta$-actin \\
\hline$\beta$-actin-R & GATACCAGCAGATTCCATACCC & qRT-PCR primer for $\beta$-actin \\
\hline GST $\Omega 1-F$ & TGTTATCGGCATTAGATCGTGTCG & qRT-PCR primer for GST $\Omega 1$ \\
\hline GST $\Omega$ 1-R & AAATCTTGAAGCGTCCAGGGTGA & qRT-PCR primer for GST $\Omega 1$ \\
\hline GST 2 2-F & TGGAGGTGAGAAGCCGATGAT & qRT-PCR primer for GST 2 \\
\hline GST $\Omega 2-\mathrm{R}$ & CTCTTCGGAACATCTGGTTACCTT & qRT-PCR primer for GST $\Omega 2$ \\
\hline GST $\Omega$ 1r-F & GGATCCGCTCTCGGGTCAGGAAGTAAGTAT & Recombinant primer for GST $\Omega 1$ \\
\hline GST $\Omega$ 1r-R & AAGCTTTCAGTGGTGGTGGTGGTGGTGTTCAAGACCTGCGTCACAATCC & Recombinant primer for GST $\Omega 1$ \\
\hline GST $\Omega$ 2r-F & GGATCCGGGAAGTTGCGGGTATA & Recombinant primer for GST $\Omega 2$ \\
\hline GST $\Omega$ 2r-R & AAGCTTTCAGTGGTGGTGGTGGTGGTGCTCCTTTCTTGCCACTACA & Recombinant primer for GST $\Omega 2$ \\
\hline
\end{tabular}


The analysis of the GST $\Omega$ s expressions in the gills and digestive glands was performed by western blotting (Harju et al., 2008). The total protein of the tissues was extracted using a RIPA lysis buffer with PMSF (Beyotime, China). Then, the concentration of soluble proteins was measured and adjusted for conformity with each other. The western blotting analysis was carried out as stated above. $\beta$-actin was used as an internal control to calibrate the expression of GST $\Omega$ s and was detected using mouse polyclonal antibodies of $\beta$-actin (1:500; Beyotime, China).

\subsection{Effect of temperature, the substrate concentrations and $\mathrm{pH}$ on arsenate reductase activities of recombinant GSTSS}

The influence of the temperature, $\mathrm{As}(\mathrm{V})$ concentration (as the substrate) and $\mathrm{pH}$ on arsenate reductase activities of recombinant GST $\Omega$ s was respectively detected. The test and data analysis were conducted in light of the methods described in section 2.5. The temperatures ranging from $17^{\circ} \mathrm{C}$ to $77^{\circ} \mathrm{C}$, As(V) concentrations ranging from $0 \mathrm{mM}$ to $100 \mathrm{mM}$ and $\mathrm{pH}$ values ranging from 3.5 to 9.0 were used.

\subsection{Complementation of arsenate sensitive E. Coli AW3110 (DE3) ( $\triangle$ arsRBC) by recombinant plasmids with GST $\Omega$}

The arsenic resistance phenotype of cells expressing GST $\Omega 1$ and GSTS 2 genes was determined in E. coli. E. coli AW3110 (DE3), which lacks the operon $\operatorname{arsRBC}$, was used for arsenate sensitivity assays (Qin et al., 2006). After being made into TSS competent cells, E. coli AW3110 (DE3) ( $\triangle a r s R B C$ ) was transformed with the recombinant plasmids pET28a-GST $\Omega$ 1, pET-28a-GST 2 and pET-28a empty vector, respectively. The single colony of E. coli AW3110 (DE3) ( $\triangle$ arsRBC) and the transformed strains were inoculated into $5 \mathrm{~mL}$ of LB medium $(40 \mu \mathrm{g} / \mathrm{mL}$ kanamycin) and incubated at $37^{\circ} \mathrm{C}$ overnight. The cultures were diluted to an OD600 of 0.1 with LB $+0.3 \mathrm{mM}$ IPTG (isopropyl- $\beta$-D-thiogalactopyranoside) and LB + Kanamycin + 0.3 mM IPTG containing different concentrations of $\mathrm{As}(\mathrm{V})$ or $\mathrm{As}(\mathrm{III})(0,100,300 \mu \mathrm{M})$. The growth of $E$. coli was monitored at an optical density of $600 \mathrm{~nm}\left(37^{\circ} \mathrm{C}\right)$ and was recorded every four hours until the cultures reached the stationary phase. The result was expressed as the average of three independent assays with a standard error.

\subsection{Bioinformatics and statistical analysis}

The nucleotide sequences were analyzed using the BLAST algorithm (http://www.ncbi.nlm.nih.gov/blast). Multiple alignments were performed with the ClustalW Multiple Alignment program (http://www. ebi.ac.uk/clustalw/). Statistical analyses were performed using SPSS 16.0 software (SPSS Inc, Chicago, USA). For all data, normality was tested by Kolmogorov-Smirnov test and homogeneity of variance was tested by Levene's test. The differences of the corresponding values were tested by a one-way analysis of variance (ANOVA) followed by a Duncan test. $P<0.05$ was accepted as statistically significant.

\section{Results}

\subsection{Bioaccumulation of arsenic in the clam R. philippinarum}

The background of arsenic in seawater was $1.07 \mu \mathrm{g} / \mathrm{L}$, and the mortality of the clams was less than $4 \%$ after inorganic arsenic exposure for 30 days. As illustrated in Fig. 1A, the basal total arsenic concentrations in the gills and digestive glands of $R$. philippinarum were $30.30 \pm 5.70 \mu \mathrm{g} / \mathrm{g} \mathrm{dw}$ and $19.56 \pm 3.36 \mu \mathrm{g} / \mathrm{g} \mathrm{dw}$, respectively, and the concentrations of the total arsenic in the digestive glands were significantly lower than those of the gills. A significant increase of arsenic concentration in gills was detected after $100 \mu \mathrm{g} / \mathrm{L} \mathrm{As}$ (III) exposure for 30 days $(P<0.05)$, while there was no significant difference in arsenic concentrations between different groups after $\mathrm{As}(\mathrm{V})$ exposure. In the digestive glands, significant arsenic accumulation was detected
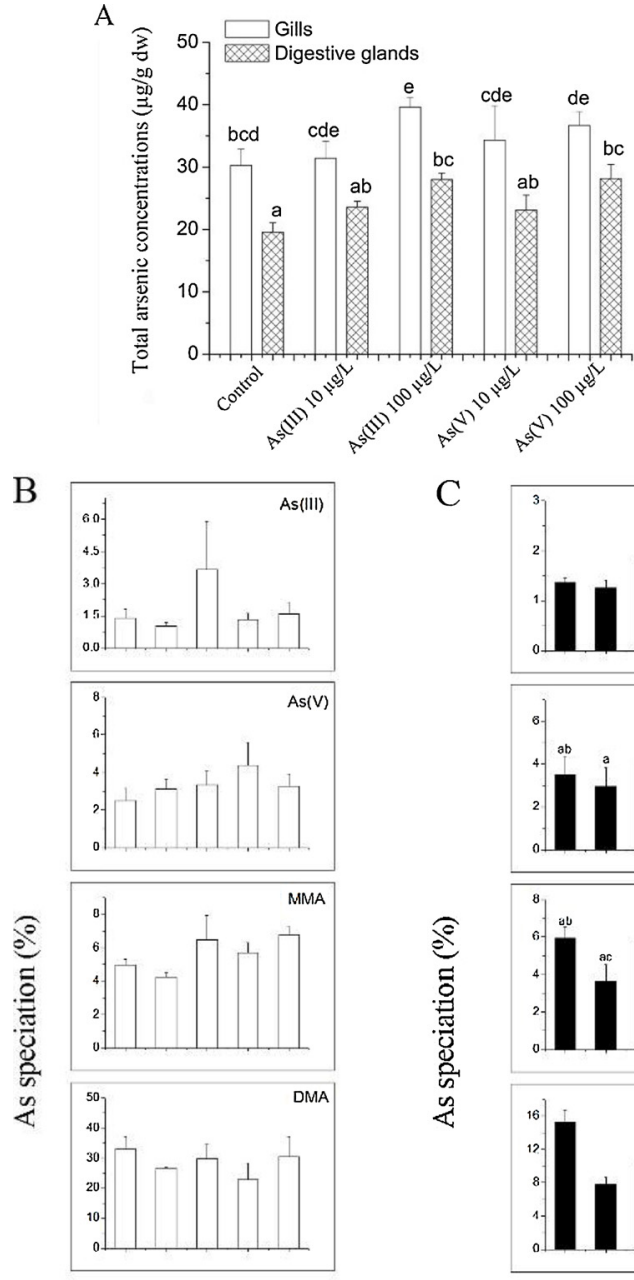

C
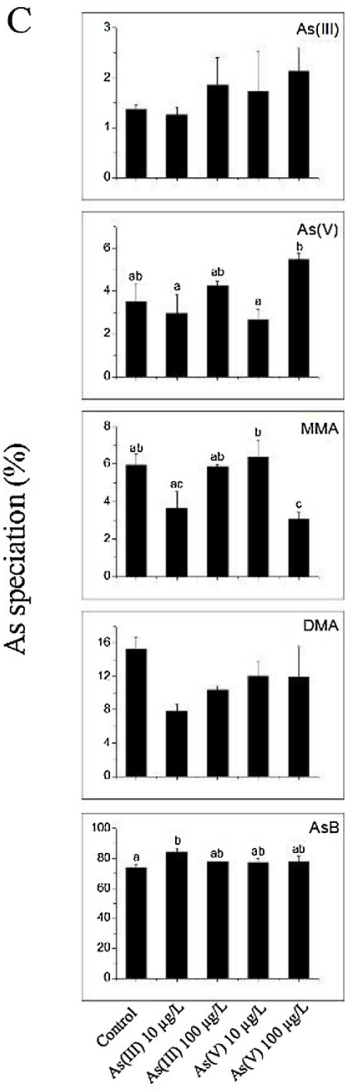

D
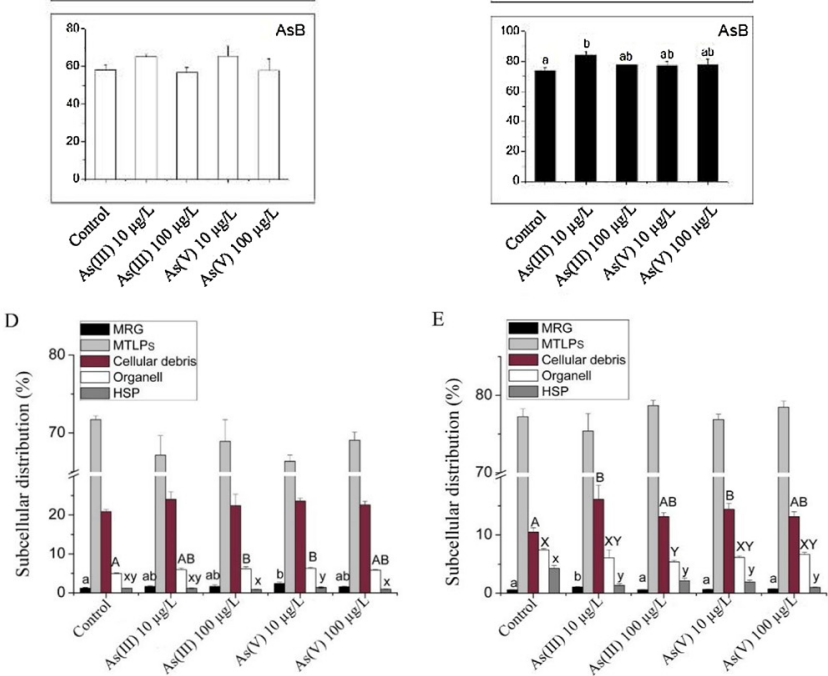

Fig. 1. Arsenic contents and subcellular distribution analysis in tissues. (A) Total As concentrations in tissues after inorganic arsenic exposure $(n=4-6)$. Arsenic percentages of different speciation (\%) in gills (B) and digestive glands (C) after arsenic exposure $(n=3)$. The white-shaded and blackshaded columns respectively represent the As percentages of different speciation (\%). Arsenic subcellular distribution (\%) in gills (D) and digestive glands (E) after arsenic exposure $(n=4)$. Metal-rich granules are shaded in black, metallothionein-like proteins in light gray, cellular debris in burgundy, organelle in white, and heat sensitive proteins in dark gray. Values are shown as means \pm SE. Different letters indicate significant differences between the treatments $(P<0.05)$. 
along with exposure to $100 \mu \mathrm{g} / \mathrm{L}$ As(III) and $100 \mu \mathrm{g} / \mathrm{L}$ As(V) $(P<$ 0.05). Thus, compared to the gills, arsenic more easily accumulated in the digestive glands of the clam $R$. philippinarum.

\subsection{Arsenic species in the clam R. philippinarum}

Fig. 1B and $\mathrm{C}$ showed the percentages of five arsenic species in the gills and digestive glands of clams, among which AsB (56.73\%-84.33\%) was the main arsenic species, followed by DMA and MMA. The percentages of inorganic arsenic were relatively small, with As(III) and As (V) accounting for, at most, $3.65 \%$ and $5.46 \%$ of the total arsenic, respectively. Inorganic arsenic exposure showed no influence on the percentages of all five arsenic species in the gills (Fig. 1B). In digestive glands, the percentages of $\mathrm{As}(\mathrm{III})$ and $\mathrm{As}(\mathrm{V})$ in the exposure groups did not significantly change compared to the control group, while the proportion of MMA in the $100 \mu \mathrm{g} / \mathrm{L} \mathrm{As}(\mathrm{V})$ exposure group decreased significantly $(P<0.05)$, and the proportion of AsB exhibited a significant increase after $10 \mu \mathrm{g} / \mathrm{L}$ As(III) exposure $(P<0.05)$ (Fig. 1C). Thus, it is suggested that inorganic arsenic can be effectively converted in organic species in $R$. philippinarum and that MMA can be quickly metabolized or converted into other forms in digestive glands.

\subsection{Subcellular distribution in tissues}

Arsenic distribution in the subcellular fractions of gills and digestive glands were given in Fig. 1D and 1E. MTLPs (66.36\%-78.69\%) were the main binding sites of arsenic in cells, followed by cellular debris $(10.50 \%-24.03 \%)$. After inorganic arsenic exposure, total arsenic content in cellular debris increased, especially in the digestive glands of $10 \mu \mathrm{g} / \mathrm{L} \mathrm{As}(\mathrm{III})$ and $\mathrm{As}(\mathrm{V})$ exposure groups $(P<0.05)$ (Fig. 1E). However, a significant reduction of arsenic content in HSP fraction appeared in the digestive glands $(P<0.05)$, as well as a slight falling in the organelles (Fig. 1E).

For better prediction of the biological toxicity of arsenic and the detoxification capability of cells, the above five subcellular components can be classified into three subcellular compartments: biologically detoxified metal fraction (BDM, including MRG and MTLPs), metal-sensitive fraction (MSF, including organelles and HSP) and cellular debris. As shown in Fig. 1F and G, although no significant differences were found after inorganic arsenic exposure, the subcellular partitioning of arsenic in BDM was the highest, followed by cellular debris and MSF. Compared to the control groups, arsenic in MSF increased in the gills, especially in $10 \mu \mathrm{g} / \mathrm{L} \mathrm{As}(\mathrm{V})$ exposure group $(P<0.05)$ (Supplementary material, Fig. S1A), but remarkably decreased in digestive glands in all exposure groups $(P<0.05)$ (Supplementary material, Fig. S1B), indicating the higher detoxification capability of digestive glands compared to gills. Additionally, arsenic in cellular debris fraction increased significantly in digestive glands, particularly in the $10 \mu \mathrm{g} / \mathrm{L} \mathrm{As}$ (III) and $10 \mu \mathrm{g} / \mathrm{L} \mathrm{As}(\mathrm{V})$ exposure groups $(P<0.05)$ (Supplementary material, Fig. S1B).

\subsection{Arsenate reductase activities and the relative mRNA expressions of GSTSs in the tissues of $R$. philippinarum}

As shown in Fig. 2A, the arsenate reductase activities of GST $\Omega$ in the digestive glands were remarkably higher than those in gills. However, it was noteworthy that the activities did not change in these tissues after different treatments. For GST $\Omega$ 1, significant transcriptional up-regulation appeared in the gills of clams treated with $10 \mu \mathrm{g} / \mathrm{L}$ As(III) (Fig. 2B) and the digestive glands of clams treated with $100 \mu \mathrm{g} / \mathrm{L}$ As(III) (Fig. 2C), respectively. After arsenic exposure, the mRNA expression level of GST 2 was remarkably up-regulated in the gills of clams from $10 \mu \mathrm{g} / \mathrm{L} \mathrm{As}$ (III) exposure group (Fig. 2D), while almost no changes were observed in other groups (Fig. 2E). In general, the transcriptional response of GSTS 1 and GST 2 to As(III) stress was more sensitive than to $\mathrm{As}(\mathrm{V})$ stress, and GSTS 1 showed a more sensitive response to inorganic arsenic exposure than GST 2 at a transcriptional level.

\subsection{Sequence analysis, recombinant protein expression and protein purification}

The complete cDNA sequences of GSTS 1 and GST 2 have been deposited in the GenBank database under accession no. ADI44318 and AEW46328, respectively. The predicted amino acid sequences of both GST $\Omega 1$ and GST 22 exhibited strong identification with glutathione Stransferases from other mollusks. For example, GST 1 shared $46 \%$ similarity with glutathione S-transferase from Haliotis madaka (ALU63761), while GST 2 was mostly homologous with glutathione Stransferase from Crassostrea virginica (XP_022346075, 48\% similarity). These two GSTQs shared a 47\% similarity with each other (Supplementary material, Fig. S2).

The purified rGST 1 and rGST $\Omega 2$ peptides were, respectively, represented as one distinct band (Supplementary material, Fig. S3, lane 4 and lane 9), with approximate molecular weights of $28 \mathrm{kDa}$ and $25 \mathrm{kDa}$, respectively, which was consistent with the molecular weights deduced from the nucleotide sequences of GST $\Omega$ genes. The concentrations of the purified rGST $\Omega 1$ and $\mathrm{rGST} \Omega 2$ were $0.169 \mathrm{mg} / \mathrm{mL}$ and $0.293 \mathrm{mg} / \mathrm{mL}$, respectively.

\subsection{Immunoblotting and immunohistochemistry}

The immunoblot analysis of the recombinant proteins produced only one single band, respectively, on the PVDF membranes that corresponded in size to purified rGST 1 and rGST 22 (Fig. S3, lane 5 and lane 10), indicating the specificity of the corresponding antibody.

The distribution and localization of GST $\Omega 1$ and GST 2 in the gills and digestive glands are illustrated in Fig. $3 \mathrm{~A}$ and B. No or less positive staining was detected in the negative controls of the different tissues. The GST $\Omega$ proteins were mainly expressed in the epithelial cells of gill filaments and hemocytes in gill cavities (Fig. 3A). In the digestive glands, intense staining was mainly exhibited in the columnar epithelial cells lining the lumen of the digestive tubules. Up-regulation of GST $\Omega 1$ and GST 2 expression was observed after $100 \mu \mathrm{g} / \mathrm{L}$ As(III) and $100 \mu \mathrm{g} /$ $\mathrm{L} \mathrm{As}(\mathrm{V})$ exposure compared to the corresponding controls (Fig. 3B). When the immunoreactivity of GST 1 and GST $\Omega 2$ was assessed through a western blot analysis in gills and digestive glands, two deepened bands were detected after arsenic exposure compared to the corresponding controls (Fig. 3C and D). Therefore, the expressions of GST $\Omega$ proteins were up-regulated for arsenic detoxification under inorganic arsenic stress.

\subsection{Effect of temperature, the substrate concentrations and $p H$ on arsenate} reductase activities of recombinant GSTSs

As shown in Fig. 4A, the highest activities of recombinant GST $\Omega 1$ and GST $\Omega 2$ were both observed at $37^{\circ} \mathrm{C}(\mathrm{pH} 7.5)$. The arsenate reductase activities of rGST $\Omega 1$ and rGST $\Omega 2$ increased with increasing As (V) concentration and reached a peak at a concentration of $60 \mathrm{mM}$ (Fig. 4B). Moreover, the arsenate reductase activities of rGST $\Omega$ s were higher at $\mathrm{pH} 4$ and 5 compared to other $\mathrm{pH}$ values (Fig. 4C). In addition, the recombinant GST $\Omega 1$ possessed higher arsenate reductase activity than GST 2.

\subsection{GSTR 1 and GSTS 2 complement arsenate-sensitive phenotype in $E$. Coli AW3110}

As illustrated in Fig. 5A and D, in the LB medium containing $0 \mu \mathrm{M}$ $\mathrm{As}(\mathrm{III})$ and $\mathrm{As}(\mathrm{V})$, the growth rate of the strains bearing empty plasmid and recombinant plasmids was apparently slower than that of $E$. coli AW3110 (DE3) ( $\triangle$ arsRBC). For comparison, after a 16-hour incubation, the OD600 of $E$. coli AW3110 ( $\triangle$ arsRBC) bearing recombinant plasmids pET-28a-GST $\Omega 1$ and pET-28a-GST 2 was 0.48 and 0.40, respectively, 


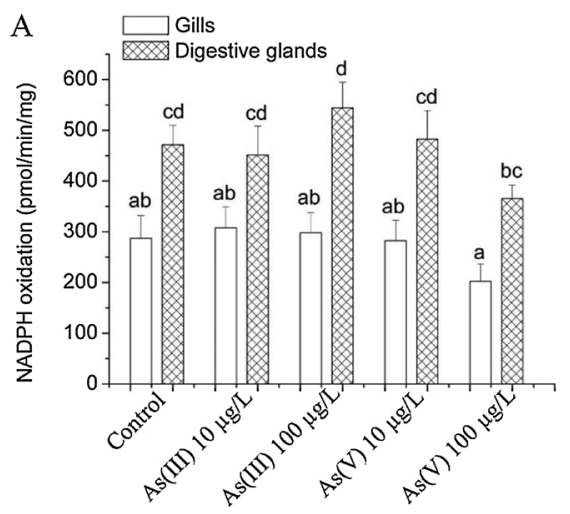

B

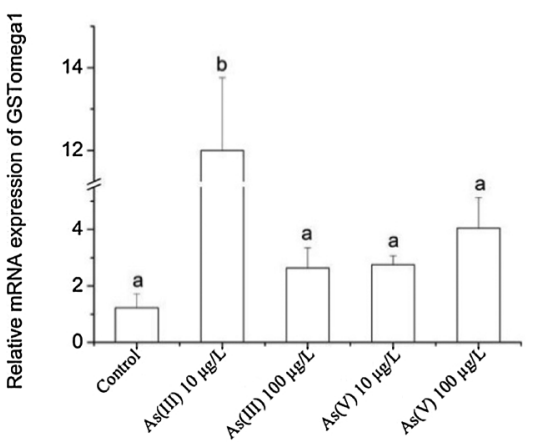

$\mathrm{D}$

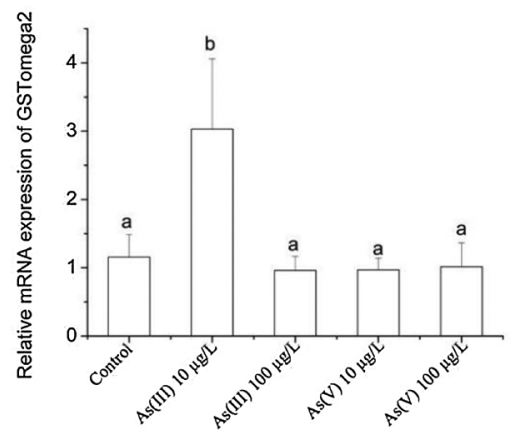

C

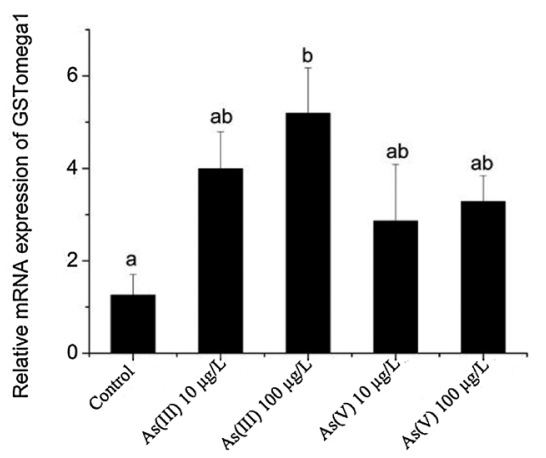

$\mathrm{E}$

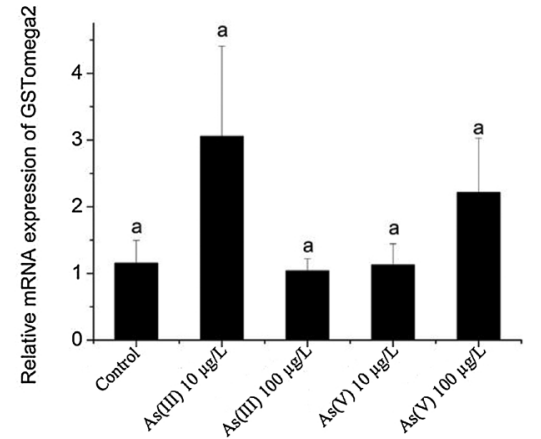

Fig. 2. Arsenate reductase activities and relative mRNA expression of GST $\Omega$ s in tissues.

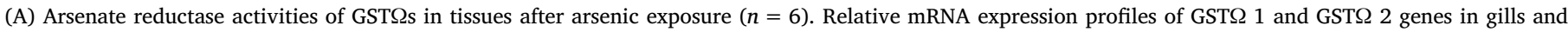

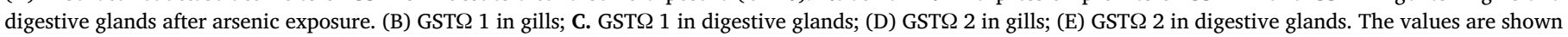
as means \pm SE $(n=4-6)$. Different letters indicate significant differences between the treatments $(P<0.05)$.

but the OD600 of E. coli AW3110 ( $\triangle$ arsRBC) was 0.79. However, the expressions of GST $\Omega 1$ and GST 2 allowed for better growth than $E$. coli AW3110 (DE3) ( $\triangle$ arsRBC) and E. coli AW3110 (DE3) ( $\triangle$ arsRBC) bearing empty plasmid, even in concentrations of As(III) as high as $300 \mu \mathrm{M}$ after more than a day of incubation (Fig. 5C), which indicated that GST 1 and GST 2 could offer resistance to As(III) in E. coli AW3110. However, the growth rate of $E$. coli AW3110 (DE3) ( $\triangle$ arsRBC) bearing recombinant plasmids was still slower than E. coli AW3110 under elevated concentrations of $\mathrm{As}(\mathrm{V})$ exposure (Fig. 5E and F).

\section{Discussion}

\subsection{Bioaccumulation and metabolism of arsenic}

The arsenic levels in the tissues of marine organisms can widely vary from less than $1 \mathrm{ppm}(\mathrm{dw})$ to more than several hundred $\mathrm{ppm}$ (dw). Concentrations often do not reflect the environmental levels of arsenic; thus, knowledge of the basal arsenic content in the tissues of marine species is fundamental to realistically evaluate the significance of both the levels and the chemical speciation of this element (Fattorini et al., 2006; Meador et al., 2004). In this clam, the amount of total arsenic was up to $30.30 \pm 5.70 \mu \mathrm{g} / \mathrm{g} \mathrm{dw}$ in the gills and $19.56 \pm 3.36 \mu \mathrm{g} / \mathrm{g} \mathrm{dw}$ in the digestive glands, respectively, indicating a higher accumulation of arsenic in gills compared to the digestive glands. This was consistent with the fact that the arsenic accumulation was tissue-specific in aquatic organisms (Phillips and Depledge, 1986; Fattorini et al., 2004b). One explanation was that gills were directly in contact with arsenic in the seawater and mainly accumulated high concentrations of arsenic in the form of adsorption rather than absorption (Neff, 1997). However, the arsenic in the gills appeared easily discharged or transferred to other tissues such as digestive glands. It was also found that arsenic was depleted rapidly in gills but its concentration decreased slowly in digestive glands when the clams Scrobicularia plana were transplanted to a clean site (Langston, 1984). In this study, the total arsenic content in gills significantly increased after $100 \mu \mathrm{g} / \mathrm{L}$ As(III) exposure and $100 \mu \mathrm{g} / \mathrm{L}$ As(V) exposure, indicating 
A

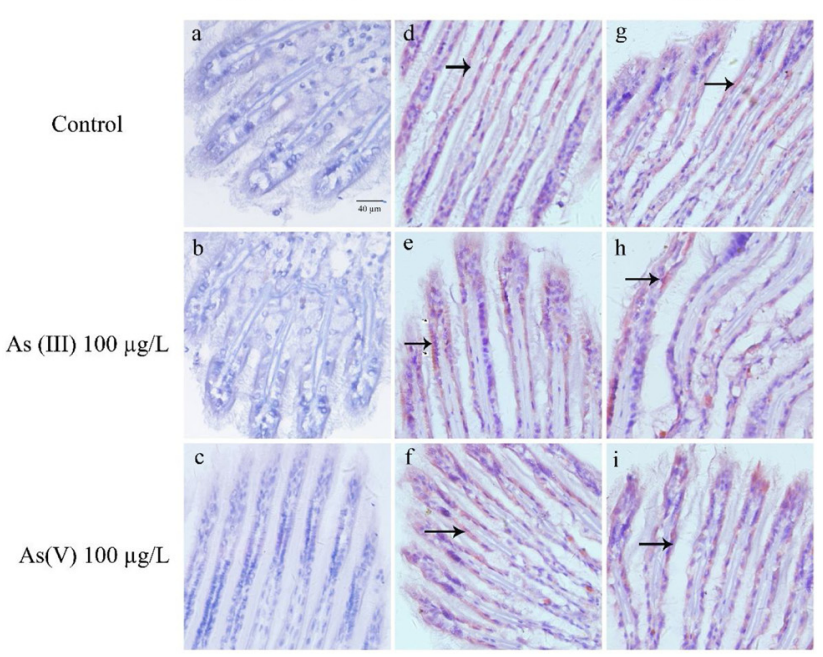

B

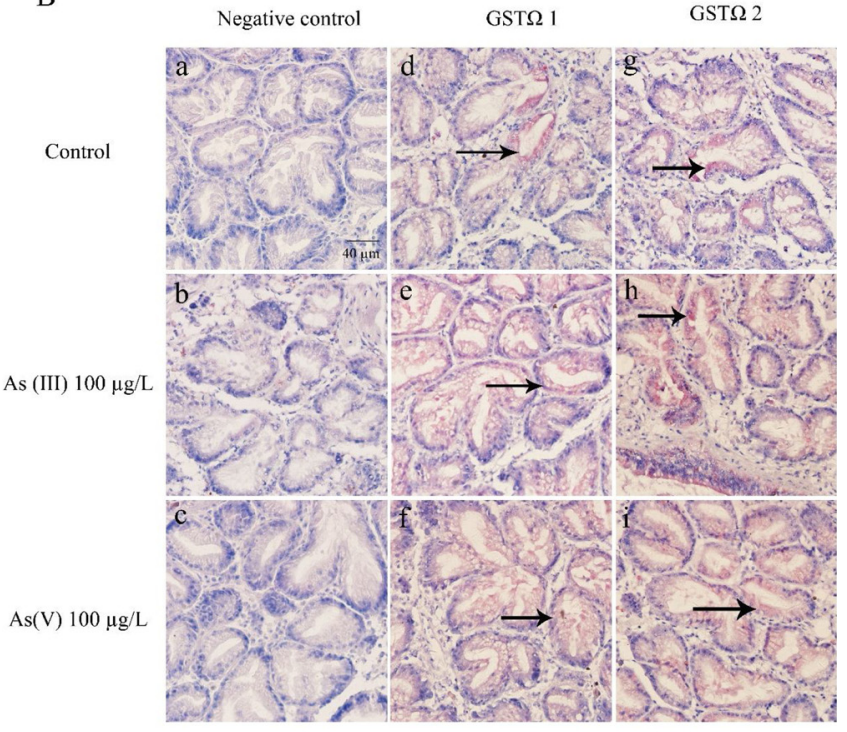

$\mathrm{C}$

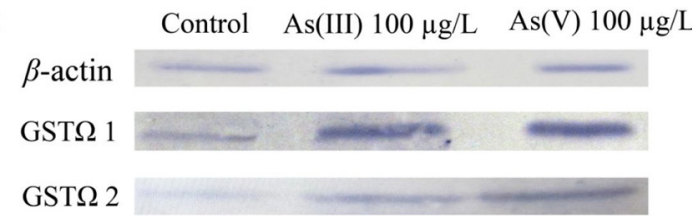

$\mathrm{D}$

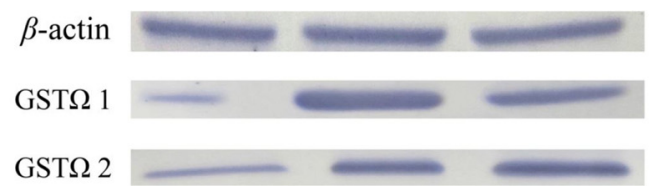

Fig. 3. Immunolocalization and western analysis of GST $\Omega$ s in tissues of $R$. philippinarum.

Immunolocalization of GST $\Omega$ proteins in gills (A) and digestive glands (B). Negative controls of the control group (a), As(III) exposure group (b), As(V) exposure group (c). Localization of GST 1 of the control group (d), As(III) exposure group (e), As(V) exposure group (f). Localization of GST 2 of the control group (g), As(III) exposure group (h), As(V) exposure group (i). Positive signal was stained red (marked with arrow) and the other signals were stained blue. Western blot analysis of GST $\Omega$ s expressions in gills (C) and digestive glands (D). $\beta$-actin expressions were used to adjust for conformity of the soluble protein concentrations. (For interpretation of the references to colour in this figure legend, the reader is referred to the web version of this article.) higher bioavailability of As(III) compared to As(V) in the clam, which was similar to a previous study on the Saccostrea cucullate oyster (Zhang et al., 2015).

In marine organisms, arsenic generally existed in the form of organic arsenic species such as AsB, arsenocholine and arsenosugars (Fattorini et al., 2004a). Among them, AsB was the main organic form and the main end product of inorganic arsenic metabolism in many marine animals (Li et al., 2003a; Zhang et al., 2013). Our study also showed that the predominant form was AsB, with low concentrations of methylated and inorganic forms in this clam. As one of the metabolism intermediates of inorganic arsenic, MMA accounted for less than $6.78 \%$ in the gills and digestive glands of the clam. After inorganic arsenic exposure, the MMA content in digestive glands decreased significantly in the $100 \mu \mathrm{g} / \mathrm{L} \mathrm{As}(\mathrm{V})$ exposure group, indicating that MMA can be quickly converted to other forms in marine invertebrates (Geiszinger et al., 2002; Zhang et al., 2015). Additionally, the DMA concentration in gills was almost twice that in digestive glands, suggesting that the conversion efficiency of inorganic arsenic was tissue specific in this clam. Therefore, digestive glands may play a vital role in arsenic metabolism and detoxification of $R$. philippinarum. Coincidentally, in vertebrates, the liver was shown to be the main site of arsenic methylation (Vahter, 2002).

\subsection{Subcellular distribution}

Organisms are able to control metal concentrations in certain tissues of their body to minimize damage from reactive forms of metals. Subcellular metal partitioning is fundamental for internal metal sequestration in different organs and tissues. Two major types of cellular sequestration involve the formation of distinct inclusion bodies and the binding of metals to heat-stable proteins. However, the compartmentalization or sequestration of metals by invertebrates is also dependent upon many factors, such as metal type, trophic transfer, and uptake routes (Cherian and Nordberg, 1983; Ng and Wang, 2005; Vijver et al., 2004). MTLPs are cysteine-rich proteins that have a significant capacity to bind metals and play an important role in the transportation and sequestration of intracellular metals (Klaassen et al., 1999). In marine animals, MTLPs were also the main subcellular distribution sites of trace metals in fish (Zhang et al., 2011, 2012a), oysters (Yu et al., 2013; Zhang et al., 2015) and polychaetes (Casado-Martinez et al., 2012). Therefore, the dominance of arsenic in MTLP fraction indicated that MTLPs probably played an important role in protecting the cells against arsenic toxicity in $R$. philippinarum as well.

From the standpoint of subcellular compartments, BDM probably played an important role in metal tolerance and resistance (Roesijadi, 1981). In this study, the clam $R$. philippinarum displayed a partitioning of arsenic to BDM to reduce arsenic toxicity. This finding was consistent with that reported in the polychaete Arenicola marina, which had most arsenic present in BDM after pollutant exposure (Casado-Martinez et al., 2012). Similarly, most Cd and Cu were also distributed in BDM in zebra mussels (Voets et al., 2009).

In digestive glands, the partitioning of arsenic to MSF decreased significantly after arsenic exposure $(P<0.05)$. However, the partitioning of arsenic to cellular debris increased remarkably in the $10 \mu \mathrm{g} / \mathrm{L}$ As(III) and $10 \mu \mathrm{g} / \mathrm{L} \mathrm{As(V)} \mathrm{exposure} \mathrm{groups.} \mathrm{Thus,} \mathrm{cellular} \mathrm{debris} \mathrm{was}$ also an important arsenic pool in marine animals (Zhang et al., 2011; Wang et al., 2011). The increasing distribution of arsenic in cellular debris might be due to the analogy of arsenic to phosphate, which functioned as the phospholipid components of cell membranes (Vijver et al., 2006). Similarly, less Zn was partitioned into MSF, and Zn in the cellular debris increased accordingly in Daphnia magna after Zn exposure (Wang and Guan, 2010). 
A

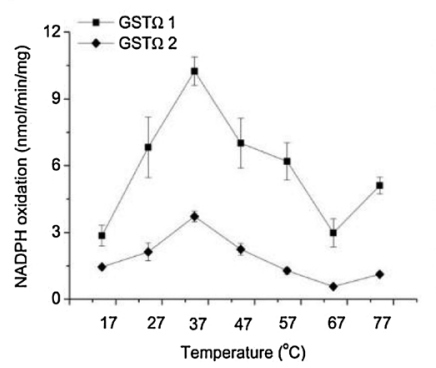

B

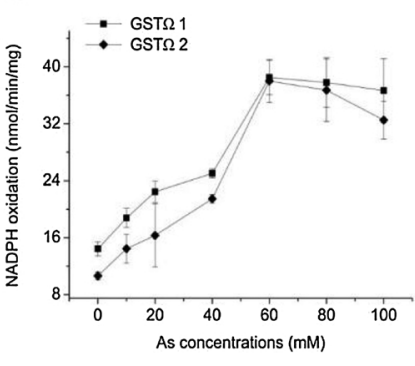

$\mathrm{C}$

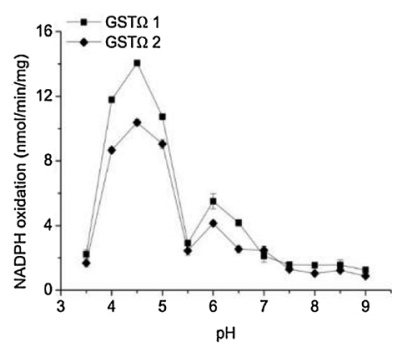

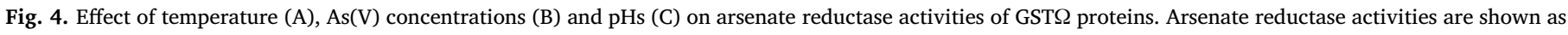
$\mathrm{nmol} \mathrm{NADPH} / \mathrm{min} / \mathrm{mg}$ protein. The values were shown as means \pm S.E. $(n=3)$.

\subsection{Arsenate reductase activities, relative $m R N A$ expressions and tissue distribution of GSTSS in R. philippinarum}

To date, little is known about the variation of GST $\Omega$ activity following exposure to arsenic in marine animals (Ventura-Lima et al., 2011a). Our study found that arsenate reductase activities of GST $\Omega$ increased dramatically in several exposure groups, indicating that GST $\Omega$ might play a role in the metabolism and detoxification of arsenic. The subsequent decrease might be due to the aggravated tissue damage (data not shown) which interfered with the normal physiological functions and metabolism of arsenic. However, GST $\Omega$ activities were restrained in the polychaete Laeonereis acuta after arsenite exposure but not significantly changed after arsenate exposure for 7 days (VenturaLima et al., 2011b). The differences might be related to the interspecific difference and exposure time.

The role of GST $\Omega$ in arsenic detoxification was further investigated at the transcript level. It was found that the transcripts of GST $\Omega 1$ and GST 2 were moderately up-regulated after arsenic exposure, suggesting a secondary role in As detoxification process. Similarly, the expression of two genes encoding GSTQs in the abalone Haliotis discus discus also significantly increased after several trace metal stimulations (Wan et al., 2009). Additionally, GST 1 was more responsive to arsenic exposure than GSTS 2. In disk abalone, HdGSTO1 also exhibited a higher response than HdGSTO2 after trace metal exposure (Wan et al., 2009).

Our results demonstrated that the transcription of the two GSTS genes were more sensitive to $\mathrm{As}(\mathrm{III})$ than $\mathrm{As}(\mathrm{V})$, which might be related to the higher bioavailability and toxicity of As(III) compared to As(V). Furthermore, these two genes displayed higher stress responses in digestive glands than in gills, suggesting that digestive glands might play a vital role in arsenic metabolism (Langston, 1984; Zhang et al., 2015). GSTS 1 had been shown to be predominantly expressed in digestive glands (Zhang et al., 2012b). A high expression level of GSTs was also detected in digestive glands of the oyster Crassostrea gigas (Boutet et al., 2004). In vertebrates, liver was also the important expression site of GSH and GST that was involved in the metabolism of arsenic (Thomas,
A

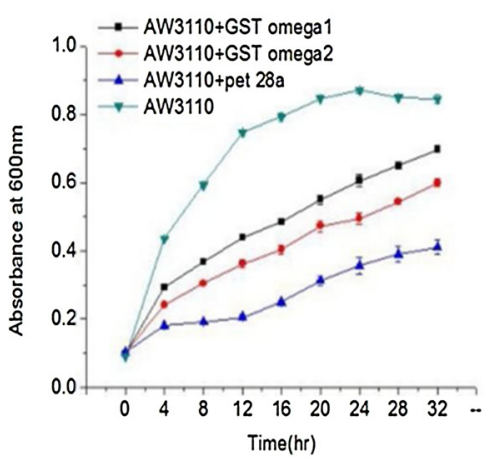

D

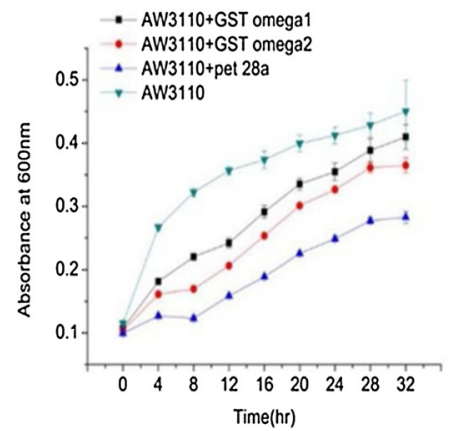

B

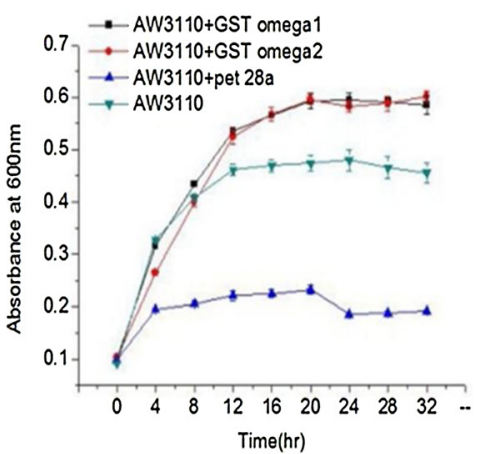

$\mathbf{E}$

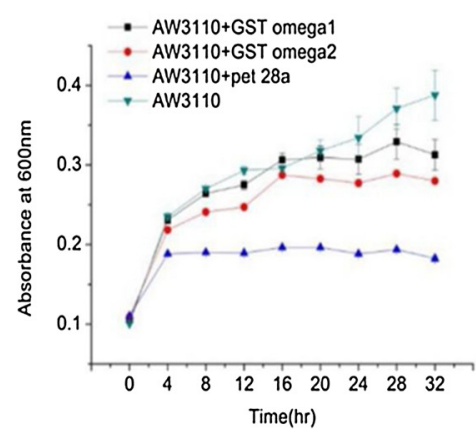

C

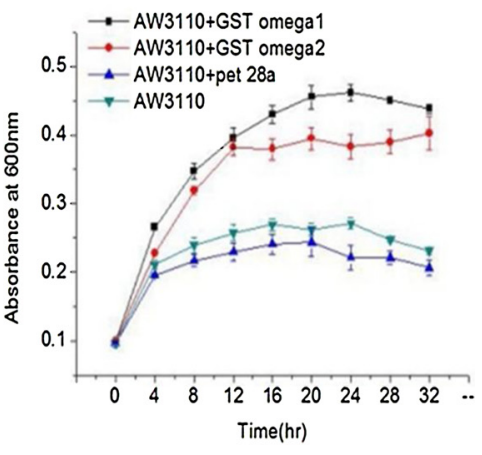

$\mathbf{F}$

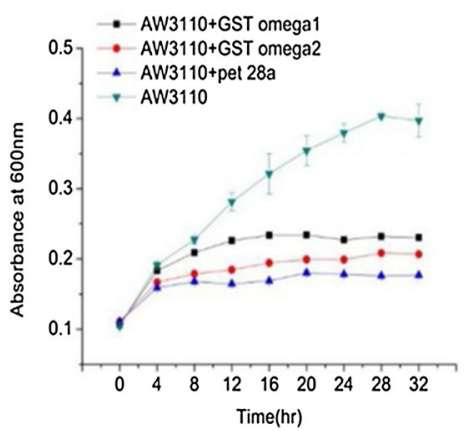

Fig. 5. Growth curve of $E$. coli with different concentrations of arsenic in the medium. A: $0 \mu \mathrm{M}$ As(III), B: $100 \mu \mathrm{M} \mathrm{As(III),} \mathrm{C:} 300 \mu \mathrm{M} \mathrm{As(III),} \mathrm{D:} 0 \mu \mathrm{M}$ As(V), E: $100 \mu \mathrm{M}$ $\mathrm{As}(\mathrm{V}), \mathrm{F}: 300 \mu \mathrm{M}$ As(V). Fig. 5 compiled data on the growth behavior of four kind strains, E. coli AW3110 (DE3) ( $\triangle$ arsRBC), E. coli AW3110 (DE3) ( $\triangle$ arsRBC)

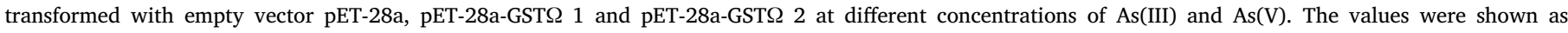
means $\pm \mathrm{SE}(n=3)$. 
2007). Therefore, GSTs might play a vital role in arsenic detoxification and metabolism in digestive glands.

An immunolocalization analysis showed that positive staining primarily appeared in the epithelial cells of the gill filaments, the hemocytes in gill cavities and the columnar epithelial cells lining the lumen of digestive tubules. There was clear immunoreactivity of GST 1 and GST 2 in digestive glands after $100 \mu \mathrm{g} / \mathrm{L} \mathrm{As(III)} \mathrm{and} 100 \mu \mathrm{g} / \mathrm{L} \mathrm{As}(\mathrm{V})$ exposure. In humans, the gene encoding GSTQ1-1 was also abundantly expressed in the liver, which was the main detoxification organ of pollutants (Yin et al., 2001). Additionally, a western blot analysis demonstrated the up-regulations of GST $\Omega$ proteins in experimental groups compared to the control groups, indicating that the modulation of GST $\Omega$ expressions was important for arsenic detoxification in this clam.

\subsection{Effect of temperature, substrate concentrations and $\mathrm{pH}$ values on arsenate reductase activities of recombinant GSTSs}

The optimal $\mathrm{pH}$ and temperature for the arsenate reductase activities of GST $\Omega$ s were between $4-5$ and $37^{\circ} \mathrm{C}$, respectively, while the arsenate reductase All0195 kept high activities at pH 7.5 and temperatures from $25^{\circ} \mathrm{C}$ to $55^{\circ} \mathrm{C}$, showing high thermal stability (Pandey et al., 2013a). With the increase of substrate concentrations, the activities of GSTQs increased until $\mathrm{As}(\mathrm{V})$ concentrations were up to $60 \mathrm{mM}$, complying with saturation kinetics. The Lineweaver-Burk Plot analysis revealed that the correlation coefficient was less than 0.9 , indicating that the kinetics of GSTRs were not in conformity with the Michaelis-Menten equation, which was similar to those of the arsenate reductase SynArsC in Synechocystis sp. PCC6803 (Li et al., 2003b). However, the activities of arsenate reductase from Staphylococcus aureus (Ji et al., 1994), rabbits (Zakharyan and Aposhian, 1999) and humans (Radabaugh et al., 2002) followed the Michaelis-Menten saturation kinetics. Thus, the arsenate reductase activity in different organisms might be affected by temperature and $\mathrm{pH}$, and the kinetics also varied between different organisms.

\subsection{GSTS 1 and GSTS 2 complement arsenate-sensitive phenotype in $E$. coli AW3110}

The function of GST $\Omega 1$ and GST 2 was further verified by complementation assays in E. coli AW3110 (DE3) ( $\triangle$ arsRBC). Our study showed that insertion expression vectors into E. coli AW3110 (DE3) ( $\triangle$ arsRBC) might have reduced the growth rate of the bacteria. Moreover, both E. coli AW3110 ( $\triangle$ arsRBC) following transformation with the conversion of recombinant plasmid pET-28a-GST 1 and pET28a-GSTR 2 grew faster than E. coli AW3110 (DE3) ( $\triangle$ arsRBC) in the $100 \mu \mathrm{M}$ and $300 \mu \mathrm{M}$ As(III) exposure groups. Hence, the GSTQs can significantly enhance the arsenite tolerance of $E$. coli AW3110 (DE3) ( $\triangle$ arsRBC), and GST $\Omega$ s were suggestive of the enzyme's significant role in arsenic detoxification. Interestingly, by contrast, the GST $\Omega$ genes did not confer resistance to As(V) exposure, possibly due to the low expression of arsenate reductase in vivo and the preference for arsenic storage or segregation in the form of $\mathrm{As}(\mathrm{V})$. Above all, GST $\Omega$ s were presumed to mainly facilitate the combination of As(III) with GSH or other thiol-containing compounds, which was beneficial to As(III) discharge in this clam (Kumagai and Sumi, 2007).

In conclusion, the bioaccumulation and metabolism of inorganic arsenic and the possible function of GST $\Omega$ proteins in detoxification were investigated in $R$. philippinarum. Inorganic arsenic was apt to accumulate in digestive glands, where the inorganic arsenic can be effectively converted into organic forms. BDM was found to be the main subcellular distribution site for arsenic. The mRNA and protein expressions of two GST $\Omega$ genes were up-regulated after arsenic exposure. Additionally, GST $\Omega$ s show arsenate reductase activity and probably promote the combination of arsenite with thiol-containing compounds. Above all, GST $\Omega$ s make a significant contribution to As detoxification among the range of GSTs even though its comparative weight cannot be fully ascertained. The roles of other GSTs in other marine organisms still need to be investigated in future studies.

\section{Acknowledgments}

We are grateful to Professor Yongguan Zhu (Institute of Urban Environment, Chinese Academy of Sciences) and Professor Barry P. Rosen (Wayne State University, USA) for their kind supply of the strain E. coli AW3110 (DE3) lack of the operon arsRBC. This work was supported by grants from National Natural Science Foundation of China (Nos. 41206105, 41576122, 41676114, 31502191), Qingdao National Laboratory for Marine Science and Technology (No. QNLM201701), Youth Innovation Promotion Association of CAS (2016196), and Youth Foundation of Shandong Natural Science Foundation (ZR2014DQ018).

\section{Appendix A. Supplementary data}

Supplementary material related to this article can be found, in the online version, at doi:https://doi.org/10.1016/j.aquatox.2018.08.016.

\section{References}

Akter, K.F., Owens, G., Davey, D.E., Naidu, R., 2005. Arsenic speciation and toxicity in biological systems. Rev. Environ. Contam. Toxicol. 184, 97-149.

Aposhian, H.V., Zakharyan, R.A., Avram, M.D., Sampayo-Reyes, A., Wollenberg, M.L., 2004. A review of the enzymology of arsenic metabolism and a new potential role of hydrogen peroxide in the detoxication of the trivalent arsenic species. Toxicol. Appl. Pharm. 198 (3), 327-335.

Boutet, I., Tanguy, A., Moraga, D., 2004. Characterisation and expression of four mRNA sequences encoding glutathione S-transferases pi, mu, omega and sigma classes in the Pacific oyster Crassostrea gigas exposed to hydrocarbons and pesticides. Mar. Biol. 146 (1), 53-64.

Casado-Martinez, M.C., Duncan, E., Smith, B.D., Maher, W.A., Rainbow, P.S., 2012. Arsenic toxicity in a sediment-dwelling polychaete: detoxification and arsenic metabolism. Ecotoxicology 21 (2), 576-590.

Cherian, M.G., Nordberg, M., 1983. Cellular adaptation in metal toxicology and metallothionein. Toxicology 28, 1-5.

Chowdhury, U.K., Zakharyan, R.A., Hernandez, A., Avram, M.D., Kopplin, M.J. Aposhian, H.V., 2006. Glutathione-S-transferase-omega [MMA(V) reductase] knockout mice: enzyme and arsenic species concentrations in tissues after arsenate administration. Toxicol. Appl. Pharmacol. 216 (3), 446-457.

Fattorini, D., Alonso-Hernandez, C.M., Diaz-Asencio, M., Munoz-Caravaca, A. Pannacciulli, F.G., Tangherlini, M., Regoli, F., 2004a. Chemical speciation of arsenic in different marine organisms: importance in monitoring studies. Mar. Environ. Res. 58 (2-5), 845-850.

Fattorini, D., Bocchetti, R., Bompadre, S., Regoli, F., 2004b. Total content and chemical speciation of arsenic in the polychaete Sabella spallanzanii. Mar. Environ. Res. 58 (2), 839-843.

Fattorini, D., Notti, A., Regoli, F., 2006. Characterization of arsenic content in marine organisms from temperate, tropical, and polar environments. Chem. Ecol. 22 (5), 405-414.

Francesconi, K.A., Edmonds, J.S., 1996. Arsenic and marine organisms. Adv. Inorg. Chem. 44, 147-189.

Gao, X., Zhou, F., Chen, C.T., 2014. Pollution status of the Bohai Sea: an overview of the environmental quality assessment related trace metals. Environ. Int. 62, 12-30.

Geiszinger, A.E., Goessler, W., Francesconi, K.A., 2002. The marine polychaete Arenicole marina: its unusual arsenic compound pattern and its uptake of arsenate from seawater. Mar. Environ. Res. 53 (1), 37-50.

Harju, T., Mazur, W., Merikallio, H., Soini, Y., Kinnula, V.L., 2008. Glutathione-S-transferases in lung and sputum specimens, effects of smoking and COPD severity. Respir. Res. 9, 80 .

Ji, G., Garber, E.A., Armes, L.G., Chen, C.-M., Fuchs, J.A., Silver, S., 1994. Arsenate reductase of Staphylococcus aureus plasmid pI258. Biochemistry 33 (23), 7294-7299.

Jomova, K., Jenisova, Z., Feszterova, M., Baros, S., Liska, J., Hudecova, D., Rhodes, C.J., Valko, M., 2011. Arsenic: toxicity, oxidative stress and human disease. J. Appl. Toxicol. 31 (2), 95-107.

Katano, S., Matsuo, Y., Hanaoka, K., 2003. Arsenic compounds accumulated in pearl oyster Pinctada fucata. Chemosphere 53 (3), 245-251.

Klaassen, C.D., Liu, J., Choudhuri, S., 1999. Metallothionein: an intracellular protein to protect against cadmium toxicity. Annu. Rev. Pharmacol. 39 (1), 267-294.

Kumagai, Y., Sumi, D., 2007. Arsenic: signal transduction, transcription factor, and biotransformation involved in cellular response and toxicity. Annu. Rev. Pharmacol. 47, $243-262$.

Langston, W., 1984. Availability of arsenic to estuarine and marine organisms: a field and laboratory evaluation. Mar. Biol. 80 (2), 143-154.

Li, W., Wei, C., Zhang, C., Van Hulle, M., Cornelis, R., Zhang, X., 2003a. A survey of arsenic species in Chinese seafood. Food Chem. Toxicol. 41 (8), 1103-1110.

Li, R., Haile, J.D., Kennelly, P.J., 2003b. An arsenate reductase from Synechocystis sp. strain PCC 6803 exhibits a novel combination of catalytic characteristics. J. Bacteriol 
185 (23), 6780-6789.

Liu, X., Zhang, L., You, L., Yu, J., Cong, M., Wang, Q., Li, F., Li, L., Zhao, J., Li, C., Wu, H., 2011. Assessment of clam Ruditapes philippinarum as heavy metal bioindicators using NMR-based metabolomics. Clean - Soil Air Water 39 (8), 759-766.

Luo, W., Lu, Y., Wang, T., Hu, W., Jiao, W., Naile, J.E., Khim, J.S., Giesy, J.P., 2010 Ecological risk assessment of arsenic and metals in sediments of coastal areas of northern Bohai and Yellow Seas, China. Ambio 39 (5-6), 367-375.

Meador, J.P., Ernest, D.W., Kagley, A., 2004. Bioaccumulation of arsenic in marine fish and invertebrates from Alaska and California. Arch. Environ. Contam. Toxicol. 47 (2), 223-233.

Neff, J.M., 1997. Ecotoxicology of arsenic in the marine environment. Environ. Toxicol. Chem. 16 (5), 917-927.

Ng, T.Y.T., Wang, W.X., 2005. Dynamics of metal subcellular distribution and its relationship with metal uptake in marine mussels. Environ. Toxicol. Chem. 24 (9), 2365-2372.

Onsanit, S., Ke, C., Wang, X., Wang, K.J., Wang, W.X., 2010. Trace elements in two marine fish cultured in fish cages in Fujian province, China. Environ. Pollut. 158 (5), 1334-1342.

Pandey, S., Shrivastava, A.K., Singh, V.K., Rai, R., Singh, P.K., Rai, S., Rai, L.C., 2013a. A new arsenate reductase involved in arsenic detoxification in Anabaena sp. PCC7120. Funct. Integr. Genomic 13 (1), 43-55.

Phillips, D., Depledge, M., 1986. Distribution of inorganic and total arsenic in tissues of the marine gastropod Hemifusus ternatanus. Mar. Ecol.-Prog. Ser. 34 (3), 261-266.

Qin, J., Rosen, B.P., Zhang, Y., Wang, G., Franke, S., Rensing, C., 2006. Arsenic detoxification and evolution of trimethylarsine gas by a microbial arsenite S-adenosylmethionine methyltransferase. P. Natl. Acad. Sci. U. S. A. 103 (7), 2075-2080.

Qin, J., Lehr, C.R., Yuan, C., Le, X.C., McDermott, T.R., Rosen, B.P., 2009. Biotransformation of arsenic by a Yellowstone thermoacidophilic eukaryotic alga. Proc. Natl. Acad. Sci. U. S. A. 106 (13), 5213-5217.

Radabaugh, T.R., Sampayo-Reyes, A., Zakharyan, R.A., Aposhian, H.V., 2002. Arsenate reductase II. Purine nucleoside phosphorylase in the presence of dihydrolipoic acid is a route for reduction of arsenate to arsenite in mammalian systems. Chem. Res. Toxicol. 15 (5), 692-698.

Rahman, M.A., Hassler, C., 2014. Is arsenic biotransformation a detoxification mechanism for microorganisms? Aquat. Toxicol. 146, 212-219.

Roesijadi, G., 1981. The significance of low molecular weight, metallothionein-like proteins in marine invertebrates: current status. Mar. Environ. Res. 4 (3), 167-179.

Sampayo-Reyes, A., Zakharyan, R.A., 2006. Inhibition of human glutathione S-transferase omega by tocopherol succinate. Biomed. Pharmacother. 60 (5), 238-244.

Thomas, D.J., 2007. Molecular processes in cellular arsenic metabolism. Toxicol. Appl. Pharm. 222 (3), 365-373.

Thomas, D.J., Nava, G.M., Cai, S.Y., Boyer, J.L., Hernandez-Zavala, A., Gaskins, H.R., 2010. Arsenic ( +3 oxidation state) methyltransferase and the methylation of arsenicals in the invertebrate chordate Ciona intestinalis. Toxicol. Sci. 113 (1), 70-76.

Vahter, M., 2002. Mechanisms of arsenic biotransformation. Toxicology 181, 211-217.

Ventura-Lima, J., Fattorini, D., Regoli, F., Monserrat, J.M., 2009. Effects of different inorganic arsenic species in Cyprinus carpio (Cyprinidae) tissues after short-time exposure: bioaccumulation, biotransformation and biological responses. Environ. Pollut. 157 (12), 3479-3484.

Ventura-Lima, J., Bogo, M.R., Monserrat, J.M., 2011a. Arsenic toxicity in mammals and aquatic animals: a comparative biochemical approach. Ecotox. Environ. Saf. 74 (3), 211-218.

Ventura-Lima, J., Ramos, P.B., Fattorini, D., Regoli, F., Ferraz, L., de Carvalho, L.M., Monserrat, J.M., 2011b. Accumulation, biotransformation, and biochemical responses after exposure to arsenite and arsenate in the estuarine polychaete Laeonereis acuta (Nereididae). Environ. Sci. Pollut. Res. Int. 18 (8), 1270-1278.

Vijver, M.G., van Gestel, C.A., Lanno, R.P., van Straalen, N.M., Peijnenburg, W.J., 2004. Internal metal sequestration and its ecotoxicological relevance: a review. Environ. Sci. Technol. 38 (18), 4705-4712.

Vijver, M.G., van Gestel, C.A., van Straalen, N.M., Lanno, R.P., Peijnenburg, W.J., 2006. Biological significance of metals partitioned to subcellular fractions within earthworms (Aporrectodea caliginosa). Environ. Toxicol. Chem. 25 (3), 807-814.

Voets, J., Redeker, E.S., Blust, R., Bervoets, L., 2009. Differences in metal sequestration between zebra mussels from clean and polluted field locations. Aquat. Toxicol. 93 (1), 53-60.

Wallace, W.G., Luoma, S.N., 2003. Subcellular compartmentalization of Cd and Zn in two bivalves. II. Significance of trophically available metal (TAM). Mar. Ecol.-Prog. Ser. 257, 125-137.

Wan, Q., Whang, I., Lee, J.S., Lee, J., 2009. Novel omega glutathione S-transferases in disk abalone: characterization and protective roles against environmental stress. Comp. Biochem. Physiol. C Toxicol. Pharmacol. 150 (4), 558-568.

Wang, W.X., Guan, R., 2010. Subcellular distribution of zinc in Daphnia magna and implication for toxicity. Environ. Toxicol. Chem. 29 (8), 1841-1848.

Wang, W.X., Yang, Y., Guo, X., He, M., Guo, F., Ke, C., 2011. Copper and zinc contamination in oysters: subcellular distribution and detoxification. Environ. Toxicol. Chem. 30 (8), 1767-1774.

Wang, Q., Zhang, L., Zhao, J., You, L., Wu, H., 2012. Two goose-type lysozymes in Mytilus galloprovincialis: possible function diversification and adaptive evolution. PLoS One 7 (9), e45148.

Waring, J., Maher, W., 2005. Arsenic bioaccumulation and species in marine polychaeta. Appl. Organomet. Chem. 19 (8), 917-929.

Xu, L., Wang, T., Ni, K., Liu, S., Wang, P., Xie, S., Meng, J., Zheng, X., Lu, Y., 2013. Metals contamination along the watershed and estuarine areas of southern Bohai Sea, China. Mar. Pollut. Bull. 74 (1), 453-463.

Yang, J., Wang, W., Wei, X., Qiu, L., Wang, L., Zhang, H., Song, L., 2010. Peptidoglycan recognition protein of Chlamys farreri (CfPGRP-S1) mediates immune defenses against bacterial infection. Dev. Comp. Immunol. 34 (12), 1300-1307.

Yin, Z.-L., Dahlstrom, J.E., Le Couteur, D.G., Board, P.G., 2001. Immunohistochemistry of omega class glutathione S-transferase in human tissues. J. Histochem. Cytochem. 49 (8), 983-987.

Yin, X.X., Chen, J., Qin, J., Sun, G.X., Rosen, B.P., Zhu, Y.G., 2011. Biotransformation and volatilization of arsenic by three photosynthetic cyanobacteria. Plant Physiol. 156 (3), 1631-1638.

Yu, X.J., Pan, K., Liu, F., Yan, Y., Wang, W.X., 2013. Spatial variation and subcellular binding of metals in oysters from a large estuary in China. Mar. Pollut. Bull. 70 (1-2), 274-280.

Zakharyan, R.A., Aposhian, H.V., 1999. Enzymatic reduction of arsenic compounds in mammalian systems: the rate-limiting enzyme of rabbit liver arsenic biotransformation is MMAV reductase. Chem. Res. Toxicol. 12 (12), 1278-1283.

Zakharyan, R.A., Sampayo-Reyes, A., Healy, S.M., Tsaprailis, G., Board, P.G., Liebler, D.C., Aposhian, H.V., 2001. Human monomethylarsonic acid (MMAV) reductase is a member of the glutathione-S-transferase superfamily. Chem. Res. Toxicol. 14 (8), 1051-1057.

Zhang, W., Wang, W.-X., 2012. Large-scale spatial and interspecies differences in trace elements and stable isotopes in marine wild fish from Chinese waters. J. Hazard. Mater. 215-216, 65-74.

Zhang, W., Huang, L., Wang, W.X., 2011. Arsenic bioaccumulation in a marine juvenile fish Terapon jarbua. Aquat. Toxicol. 105 (3-4), 582-588.

Zhang, W., Huang, L., Wang, W.X., 2012a. Biotransformation and detoxification of inorganic arsenic in a marine juvenile fish Terapon jarbua after waterborne and dietborne exposure. J. Hazard. Mater. 221-222, 162-169.

Zhang, L., Qiu, L., Wu, H., Liu, X., You, L., Pei, D., Chen, L., Wang, Q., Zhao, J., 2012b. Expression profiles of seven glutathione S-transferase (GST) genes from Venerupis philippinarum exposed to heavy metals and benzo[a]pyrene. Comp. Biochem. Physiol. C Toxicol. Pharmacol. 155 (3), 517-527.

Zhang, W., Wang, W.X., Zhang, L., 2013. Arsenic speciation and spatial and interspecies differences of metal concentrations in mollusks and crustaceans from a South China estuary. Ecotoxicology 22 (4), 671-682.

Zhang, W., Guo, Z., Zhou, Y., Liu, H., Zhang, L., 2015. Biotransformation and detoxification of inorganic arsenic in Bombay oyster Saccostrea cucullata. Aquat. Toxicol. 158, 33-40. 